\title{
Bear trade in the Czech Republic: an analysis of legal and illegal international trade from 2005 to 2020
}

\author{
Chris R. Shepherd ${ }^{1}$ (1) · Jitka Kufnerová ${ }^{2,3} \cdot$ Tomáš Cajthaml $^{3}$ • Jaroslava Frouzová ${ }^{3} \cdot$ Lalita Gomez $^{1,4}$
}

Received: 29 June 2020 / Revised: 26 August 2020 / Accepted: 11 September 2020 / Published online: 24 October 2020

(C) The Author(s) 2020

\begin{abstract}
There is a large demand for bear parts in the Czech Republic, and this drives legal and illegal trade in various bear species sourced from outside the country. From 2010 to 2018, the Czech Republic reported legal imports of 495 bear parts, mostly as trophies from Canada and Russia. Illegal trade in bear parts and derivatives for medicine as well as trophies persists as evidenced by the number of seizures made by the Czech Environmental Inspectorate during this same period. From January 2005 to February 2020, 36 seizures involving bears, their parts and derivatives, were made totalling 346 items. Most cases involved trophies (skins, skulls, taxidermies) predominantly from Canada, Russia and the USA, followed by traditional medicines claiming to contain bear parts mostly from Vietnam and China. Three cases involved souvenirs or jewellery, and one case involved live bear cubs. The greatest number of seizures made originated from Vietnam, followed by Canada and Russia. As all countries involved in these incidents are Parties to the Convention on International Trade in Endangered Species of Wild Fauna and Flora (CITES), there is a mechanism in place to jointly tackle this illegal trade. International collaboration is essential if efforts to end the illegal international trade in bear parts and derivatives are to succeed.
\end{abstract}

Keywords Bears $\cdot$ CITES $\cdot$ Seizures $\cdot$ Traditional medicine $\cdot$ Trophy hunting $\cdot$ Wildlife trade

\section{Introduction}

The unsustainable and illegal trade in wildlife has become a leading impediment to the preservation of biodiversity (van Uhm 2016; WWF 2018; UNODC 2020). Illegal wildlife trade involves multiple source, transit and destination countries, impacting species on a global scale. The incessant demand for and high commercial value of wildlife as pets, food, traditional medicines, luxury goods, ornaments, trophies, etc. is driving the declines and extinctions of an ever-expanding list of species (Harrison et al. 2016; Voigt et al. 2018; Stanford

Chris R. Shepherd

chris.shepherd@mcrsociety.org

1 Monitor Conservation Research Society, Big Lake Ranch, Canada

2 Czech Environmental Inspectorate, Prague, Czech Republic

3 Faculty of Science, Institute for Environmental Studies, Charles University, Prague, Czech Republic

4 Oxford Wildlife Trade Research Group, Oxford Brookes University, Oxford, UK et al. 2020). Tigers, for example, coveted for traditional medicinal use and trophies, are on the brink of extinction (Wong and Krishnasamy 2019), and depletion of Asian pangolin species has resulted in the over-harvesting and illegal trafficking of African pangolins in tremendous volumes (Challender et al. 2016; Gomez et al. 2016; Heinrich et al. 2016). Lesser studied species such as tortoises and freshwater turtles, amphibians and songbirds are being silently extinguished for the exotic pet trade (Auliya et al. 2016; Lee et al. 2016; Nijman et al. 2019; Shepherd et al. 2019; Stanford et al. 2020). The list of species threatened by illegal and unsustainable trade is growing, and among these species in peril are bears.

There are only eight extant species of bears in the world, all of which are affected by wildlife trade, although some more than others. Bears are hunted for their gall bladder and bile coveted in traditional Asian medicine, their meat and paws are considered by some to be delicacies and their parts are prized as trophies (Foley et al. 2011; Burgess et al. 2014). Live bears are also hunted for the pet trade, to stock bear bile extracting facilities (misleadingly known as bear farms), for wildlife 
exhibitions and performances, bear baiting, etc. (Gupta et al. 2007; D'Cruze et al. 2011; Livingstone et al. 2018). The demand for bears is high and fuels both a legal and black market trade in bear species that are having detrimental impacts on wild populations. This is particularly evident in the Asian region, where bear species are legally protected throughout their range. The illegal wildlife trade has been identified as the leading threat to bears, especially the Asiatic black bear Ursus thibetanus, sloth bear Melursus ursinus and sun bear Helarctos malayanus (Mills and Servheen 1994; Shepherd and Nijman 2007; Burgess et al. 2014; Gomez et al. 2020).

The illegal trade of bears in Asia has been well documented including the international trafficking of bears from Asia to other parts of the world (Foley et al. 2011; Burgess et al. 2014; Lee et al. 2015; Willcox et al. 2016; Nijman et al. 2017; Crudge et al. 2018; Gomez and Shepherd 2018; Gomez and Shepherd 2019). While we know the trade in bears is prevalent outside of Asia, it remains poorly understood in terms of its extent, legality as well as trade dynamics. According to Burgess et al. (2014), the USA and New Zealand have seized a significant number of shipments containing illegal bear items, mainly derivatives, exported from Asia (69\% and $50 \%$, respectively, of all their bear-related seizures). Its scale and magnitude, however, is unknown, although it is believed to be largely fuelled by the demand for traditional medicine products by Asian communities in these countries (Burgess et al. 2014). Europe is considered one of the biggest importers of bear trophies which are reportedly leading to unsustainable levels of trophy hunting in some places, but the extent of the impact is unclear (Gaius 2018).

Recent anecdotal information has also revealed an illegal trade in bear parts and derivatives in the Czech Republic. The only bear species in the Czech Republic is the brown bear Ursus arctos, though the population has been greatly decimated by hunting during the seventeenth and eighteenth century, and its continued existence in this country is uncertain (McLellan et al. 2017). Nevertheless, brown bears in the Czech Republic are afforded the highest level of protection, and no hunting is permitted. It is uncertain what is driving the trade in bear parts in the Czech Republic or where they are being sourced from. Clearly further study is warranted to understand the dynamics and potential threat to bears including possible illegal trade emanating from Asia.

Here we analyse seizures of bears, bear parts and derivatives, to determine the role of the Czech Republic in the illegal trade of bears and make recommendations to disrupt the trade. We also examine the legal import of bear parts and derivatives into the Czech Republic to gauge the overall size of the import of bears into the Czech Republic and to better understand the demand.

\section{Legislation regulating the trade in bears in the Czech Republic}

All eight of the world's extant bear species are listed in the Appendices of the Convention on International Trade in Endangered Species of Wild Fauna and Flora (CITES), to which the Czech Republic is a Party. CITES is implemented and enforced in the Czech Republic under the Czech CITES Act 100/2004 on protection of wild species of flora and fauna by regulating the trade with them and about other measures for their protection ( also known as the Act on trade in endangered species). Penalties for smuggling bear parts and derivatives into the Czech Republic depend on the species involved. Illegal trade involving a bear species listed in Annex A of EU Council Regulation (EC) No. 338/97 (all bear species excluding American black bear Ursus americanus and polar bear Ursus maritimus) is a criminal offence and is punishable with imprisonment of up to 3 years, confiscation of the specimen(s) and a ban of activities associated with the offence. If the accused acted as a member of an organized group, the maximum prison sentence is increased to up to 5 years. If the group operated internationally, the maximum prison sentence is further increased to between 2 and 8 years. If the violation involved 25 or more specimens of a species listed in Annex B (i.e., American black bear and polar bear), the case is prosecuted in accordance with the regime for illegal trade of Annex A species.

Cases involving Annex A species are prosecuted by police or customs, and in these cases, the Czech Environmental Inspectorate usually carries out the initial investigation, identifies illegal activities and provides expert opinions for courts. The Czech Environmental Inspectorate is one of the main enforcement agencies (together with the customs and national park authorities) responsible for investigation, identification of law offences and law enforcement in the field of nature conservation and CITES. Cases involving Annex B species are prosecuted by the Czech Environmental Inspectorate. If the state attorney or a judge considers that the offence posed little risk to the community, the case is treated as a civil law offence, punishable with a fine of up to CZK1,500,000 (approx. USD66,180) and confiscation of the specimen(s). The Czech Environmental Inspectorate also prosecutes cases considered as civil law offences, including cases involving countries within or outside the EU (maximum fine of CZK1,500, 000 (approx. USD66,180) and confiscation of the specimen(s)) and poaching or illegal trade of local Czech bear specimens (maximum fine of CZK100,000 (USD4400)). If the offender is a corporation, the maximum fine is CZK2,000,000 (USD88,241).

Brown bears are protected under various pieces of legislation in the Czech Republic. As a native species, it is protected under the Nature and Landscape Conservation Act (114/1992) and as a CITES-listed species under the national CITES Act 
(100/2004) and EU-related CITES legislation (EC 338/97 and related implementing pieces of legislation). Under the Nature and Landscape Conservation Act, the killing of brown bears in the Czech Republic is prohibited, as is possession of live brown bears or any parts or derivatives of a brown bear without special permit granted by government and violations are punishable by imprisonment for up to 3 years, prohibition of activity or confiscation of belongings.

\section{Methods}

We looked at seizure records provided by the Czech Environmental Inspectorate as the CITES enforcement focal point of the Czech Republic, from January 2005 to February 2020 , as well as associated prosecution records, which included details of individuals arrested/prosecuted, volumes and origins of shipments seized. Based on this, we analysed the type and source of the contraband and the country or territory of origin reported in each instance.

As the Czech Republic is a Party to CITES, we also accessed the CITES Trade Database for the years 2005 to 2018 (2018 is the most recent data available at the time of writing), to determine which countries are important sources of legal and illegal bear parts and derivatives for the Czech Republic and to identify the most commonly imported bear derivatives to the Czech Republic. When interrogating the CITES Trade Database, we examined all records of import into the Czech Republic of Ursidae, looking at all sources and all purpose codes.

We also used the data to determine if native brown bears are appearing in seizures made in the Czech Republic.

\section{Results}

\section{Illegal trade}

From January 2005 to February 2020, there were a total of 36 seizures involving various bears species, their parts and derivatives, totalling 346 items in the Czech Republic (Table 1). Most cases $(n=19)$ involved trophies (skins, skulls, taxidermies), followed by traditional medicines $(n=13)$. Three cases involved souvenirs or jewellery, one involved live bear cubs and in two cases the items seized were not reported. In six cases, the items, all trophies, were returned once the required paperwork was provided (Fig. 1).

Seizures were made of products coming from eight countries and territories, outside of the Czech Republic (Table 2). For two cases, the sources were unknown or not reported and involved one trophy (whole bear taxidermy) and 187 bear bile vials. The greatest number of seizures $(n=9)$ were made of products coming from Vietnam. The majority of items seized were manufactured bear bile medicines ( 5 incidents, 36 items) followed by gall bladder ( 2 incidents, 2 gall bladders) and jewellery made from bear teeth ( 2 incidents, 2 bear teeth pendants).

After Vietnam, the greatest number of cases involved bear parts coming from Canada and Russia with seven seizures each. All cases involving Canada were of the skulls and skins and one bear taxidermy. Most seized parts were of American black bears ( 6 incidents amounting to 8 animals), with the exception of two polar bear skulls seized in one incident in 2018. Cases involving Russia were mostly of trophies (i.e. skins and skulls) ( 5 incidents amounting to 6 brown bears) followed by one case involving three packages each containing ten bear bile pills (species unknown) and one case involving two live brown bear cubs. The two cubs were seized in 2017 and were the only live bears reported in this dataset. In four of the 14 cases involving Canada and Russia, the seized commodities were returned as the required paperwork was later provided.

The remaining incidents involved China $(n=2)$, the Czech Republic $(n=2)$, the USA $(\mathrm{n}=4)$, Georgia $(n=1)$, Hong Kong $(n=1)$, Slovakia $(n=1)$ and two of unreported origin.

\section{Legal trade}

According to the CITES Trade Database, between 2005 and 2018, there were 221 records relating to imports of bears, their parts and derivatives to the Czech Republic involving at least six species of bear, i.e. American black bear, brown bear, polar bear, Asiatic black bear, sloth bear and sun bear. The majority of imports were from Canada (67.4\%) followed by Russia (14\%) (Table 3). Other countries exporting bears and parts to the Czech Republic included Croatia (4.0\%), India $(0.9 \%)$, Greenland $(0.45 \%)$, Myanmar $(0.9 \%)$, Norway $(0.9 \%)$, Romania $(2.7 \%)$, Switzerland (1.4\%), Tajikistan $(0.45 \%)$, Tunisia $(0.45 \%)$, Ukraine $(0.45 \%)$, the USA $(5.4 \%)$ and Vietnam (0.45\%) (Fig. 2).

Of the 221 import records involving bears into the Czech Republic, 93.2\% were of bear trophies encompassing whole bears and their parts (bones, claws, feet, genitalia, meat, skins and skulls) amounting to between 639 items (importer reported quantities) and 1018 items $+92.7 \mathrm{~kg}$ of meat (exporter reported quantities) (Table 3). This comprised three bear species, American black bear (103 records), brown bear (62 records) and polar bear (41 records). Needless to say, the majority of these were from wild bears with the exception of four records ( 3 from the USA and 1 from Canada) which reported the source and seized (sourced code I) and seven records ( 5 from Canada and 2 from Russia) that were preconvention specimens (source code $\mathrm{O}$ ). Bear trophies were imported predominantly under three purpose codes, i.e. hunting trophy $(\mathrm{H}), 106$ records; personal $(\mathrm{P}), 61$ records; and 
Table 1 Bear commodities seized in the Czech Republic from January 2005 to February 2020 including origins of commodities seized and total quantities seized of each commodity

\begin{tabular}{|c|c|c|c|c|c|c|c|c|c|c|c|}
\hline \multirow[t]{2}{*}{ Commodity seized } & \multicolumn{10}{|c|}{ Origin } & \multirow[t]{2}{*}{ Tota } \\
\hline & $\mathrm{CA}$ & $\mathrm{CN}$ & $\mathrm{CZ}$ & GE & HK & RU & SK & US & $\mathrm{VN}$ & Unknown & \\
\hline \multicolumn{12}{|l|}{ Pet } \\
\hline Live (cubs) & & & & & & 2 & & & & & 2 \\
\hline \multicolumn{12}{|l|}{ Souvenir/Jewellery } \\
\hline Claw (pendant) & & & & & & & & 1 & & & 1 \\
\hline Tooth (gold pendant) & & & & & & & & & 1 & & 1 \\
\hline Tooth (silver pendant) & & & & & & & & & 1 & & 1 \\
\hline \multicolumn{12}{|l|}{ Traditional medicine } \\
\hline Bear bile (cream) & & & & & 22 & & & & 5 & & 27 \\
\hline Bear bile (suppository) & & 35 & & & & & & & & & 35 \\
\hline Bear bile (vials) & & & & & & 30 & & & 31 & 187 & 248 \\
\hline Bear bile in vodka & & & 1 & & & & & & & & 1 \\
\hline Gall bladder & & & & & & & & & 2 & & 2 \\
\hline \multicolumn{12}{|l|}{ Trophy } \\
\hline Skin & 7 & & & & & 1 & & 2 & & & 10 \\
\hline Skin (tanned) & & & 1 & & & 2 & 1 & & & & 4 \\
\hline Skin (untanned) & & & & & & & 1 & & & & 1 \\
\hline Skull & 6 & & & & & 2 & & 1 & & & 9 \\
\hline Taxidermy (whole) & 1 & & & & & & & & & 1 & 2 \\
\hline Unknown & & & & 1 & & 1 & & & & & 2 \\
\hline Total & 14 & 35 & 2 & 1 & 22 & 38 & 2 & 4 & 40 & 188 & 346 \\
\hline
\end{tabular}

CA Canada, CN China, CZ Czech Republic, GE Georgia, HK Hong Kong, $R U$ Russia, SK Slovakia, US USA and $V N$ Vietnam

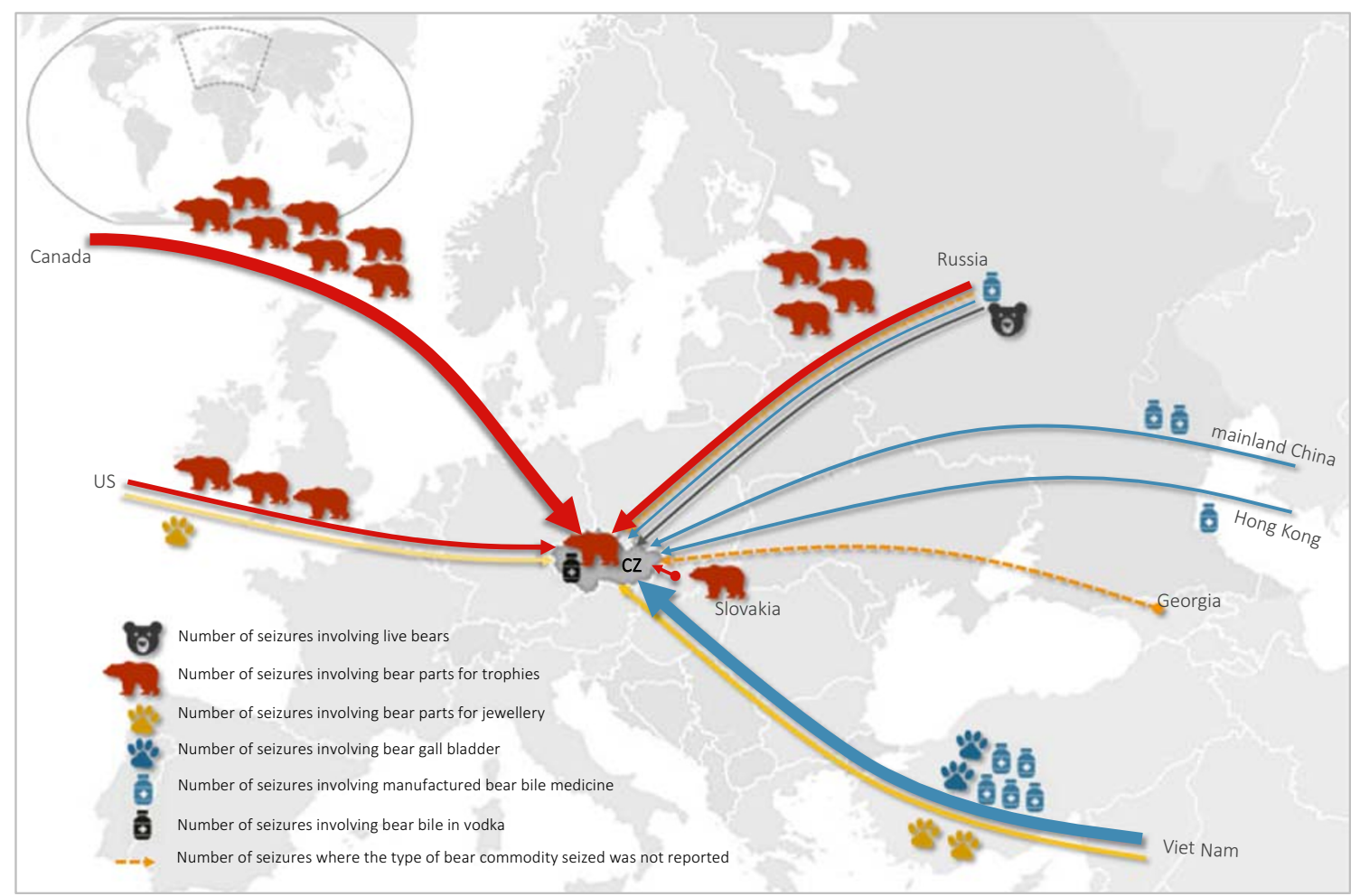

Fig. 1 The number of seizure records involving bears, their parts and derivatives that occurred in the Czech Republic from 2005 to February 2020 , including origins of seized shipments and the commodities seized in each incident. Not included in this figure are quantities of each commodity seized, which are referred to in Table 1 
Table 2 The countries implicated in the trafficking of bear parts to the Czech Republic including frequency of shipments originating from these countries from 2005 to February 2020

\begin{tabular}{|c|c|c|c|c|}
\hline $\begin{array}{l}\text { Origins of } \\
\text { commodity } \\
\text { seized }\end{array}$ & Commodity* & $\begin{array}{l}\text { Number } \\
\text { of seizures }\end{array}$ & Species identified & Outcome/penalty \\
\hline Canada & $\begin{array}{l}\text { Skull, skin, bear } \\
\text { taxidermy }\end{array}$ & 7 & $\begin{array}{l}\text { American black } \\
\text { bear polar bear }\end{array}$ & $\begin{array}{l}\text {-In three cases, seized items were returned once required documents were } \\
\text { provided-Only three cases resulted in fines, i.e. CZK2000 ( USD90), } \\
\text { CZK5000 ( USD220) and CZK20 000 ( USD885) (Polar Bear skulls along } \\
\text { with } 1 \text { walrus skull and } 1 \text { whale skull) }\end{array}$ \\
\hline China & $\begin{array}{l}\text { Bear bile } \\
\quad \text { suppositories }\end{array}$ & 2 & Unknown & -Both cases resulted in fines of CZK1000 ( USD45) \\
\hline Czech Republic & $\begin{array}{l}\text { Bear bile in } \\
\text { vodka, skin }\end{array}$ & 2 & Brown bear & $\begin{array}{l}\text {-The seized skin was returned as proper documentation was later provided-A fine } \\
\text { of CZK2000 ( USD } 90) \text { for seized bear bile in vodka }\end{array}$ \\
\hline Georgia & Unknown & 1 & Unknown & -A bear item was seized, but no other details reported \\
\hline Hong Kong & Bear bile cream & 1 & Unknown & -A fine of CZK2200 ( USD100) \\
\hline Russia & $\begin{array}{l}\text { Bear bile, live, } \\
\text { skins, skull }\end{array}$ & 7 & Brown bear & $\begin{array}{l}\text {-In one case, seized item was returned once proper documentation was provided } \\
\text {-Only three cases involving the skins and skull resulted in fines, CZK3000 }(\sim \\
\text { USD130), CZK4000 ( USD180) and CZK5000 ( USD220) -One case still } \\
\text { ongoing }\end{array}$ \\
\hline Slovakia & Skins & 1 & Unknown & -Skins seized, but no other details reported \\
\hline Unknown & $\begin{array}{l}\text { Bear bile vials, } \\
\text { stuffed }\end{array}$ & 2 & $\begin{array}{r}\text { American black } \\
\text { bear (stuffed) }\end{array}$ & -No details reported \\
\hline USA & $\begin{array}{l}\text { Claw pendant, } \\
\text { skin, skull }\end{array}$ & 4 & $\begin{array}{l}\text { American black } \\
\text { bear, brown } \\
\text { bear }\end{array}$ & $\begin{array}{l}\text {-In one case, seized item was returned once proper documentation was provided } \\
\text {-Two cases involving the skins and skull resulted in fines, CZK1000 }(\sim \\
\text { USD45) and CZK500 ( USD20) } \\
\text {-One case still ongoing }\end{array}$ \\
\hline Vietnam & $\begin{array}{l}\text { Bear bile, gall } \\
\text { bladder, } \\
\text { jewellery }\end{array}$ & 9 & $\begin{array}{l}\text { Asiatic black bear } \\
\text { brown bear }\end{array}$ & $\begin{array}{l}\text {-six cases resulted in fines ranging from CZK1000 to CZK5000 ( } \\
\text { USD45-USD220) -Two cases still ongoing }\end{array}$ \\
\hline
\end{tabular}

*Refer to Table 1 for detailed breakdown of commodities seized and quantities

commercial (T), 24 records. Canada was the greatest exporter of hunting trophies to the Czech Republic ( $70.1 \%$ of records) followed by Russia ( $13.1 \%$ of records) and the USA $(5.3 \%$ of records), while the greatest number of trophy items were from Canada, Russia and Croatia (Table 3).

To a lesser extent, live bears were also imported into the Czech Republic in at least 13 records involving six bear species and ranging from 15 (importer reported quantities) to 16 (exporter reported quantities) animals (Table 3). There were eight countries that exported live bears to the Czech Republic, of which, Russia had the highest number of records $(n=4)$ and then India $(n=2)$ and Myanmar $(n=2)$. The remaining countries were Switzerland, Romania, Tajikistan, Tunisia and the USA with one record each. Live bears were imported primarily under purpose code $\mathrm{Z}$, zoos ( 8 records) followed by $\mathrm{Q}$, circus/travelling exhibition (3 records); B, captive breeding (1 record); and $\mathrm{T}$, commercial (1 record). Most live bears were declared as source code C, implying captive bred animals (5 records); W, wild-caught (5 records) followed by $\mathrm{F}$, born in captivity (3 records).

There were also two import records in 2010 of bear derivatives from Ukraine $(0.15 \mathrm{~L})$ and Vietnam $(2.75$ $\mathrm{kg}$ ), although the source of both items was reported as seized (source code I).

\section{Discussion and recommendations}

There is clearly a demand for bear parts and derivatives in the Czech Republic which fuels the trade in various bear species though this does not appear to be sourced from local populations of brown bears in the country. Bear trophies are the main driver of demand as evident by the number of records of the claws, skulls and skins imported by the Czech Republic within the CITES Trade Database and by the seizure of the skins, skulls and taxidermy products. The number of claws exported to the Czech Republic is noteworthy (Canada reported exporting 343 claws to the Czech Republic), and it is assumed these are for talismans or jewellery. Canada and Russia are the biggest exporters of trophies to the Czech Republic both legally and illegally. It is unclear why trophies that can be legally imported were smuggled into the country unless they were illegally acquired in the country of origin. This is not without merit considering both countries have been previously implicated in the international trafficking of bears and their 


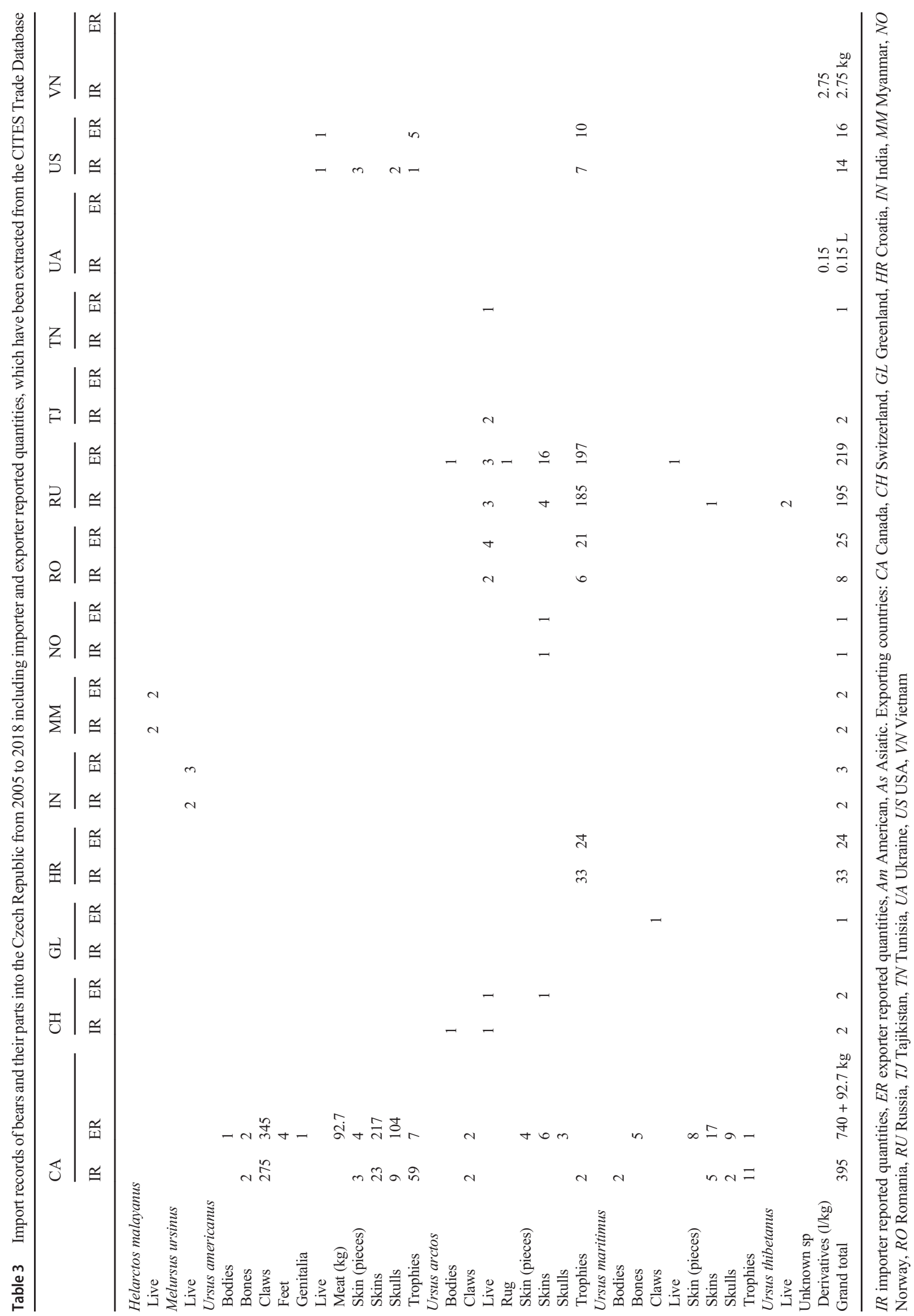


Fig. 2 The number of legal import records of bears and parts into the Czech Republic from 2005 to 2018 and exporting countries: $\mathrm{CA}$, Canada; $\mathrm{CH}$, Switzerland; GL, Greenland; HR, Croatia; IN, India; MM,

Myanmar; NO, Norway; RO, Romania; RU, Russia; TJ,

Tajikistan; TN, Tunisia; UA, Ukraine; US, USA; VN, Vietnam. This information has been extracted from the CITES Trade Database (https://trade.cites.org/)

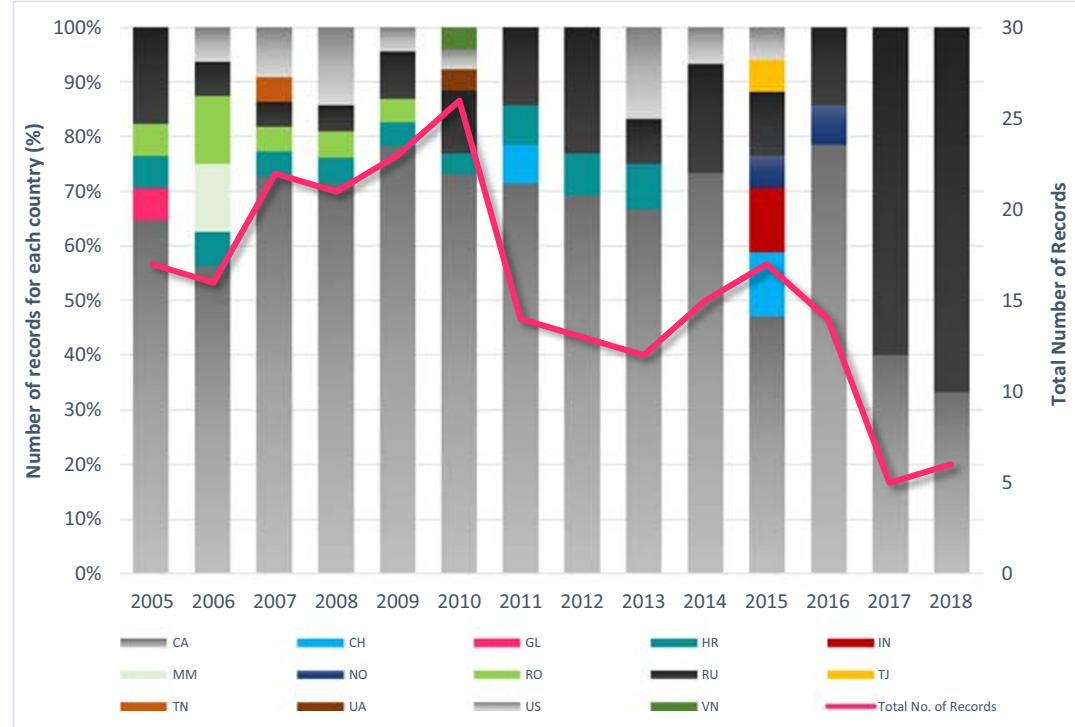

parts (Foley et al. 2011; Burgess et al. 2014; Gaius 2018). In 2004, the EU implemented a ban on imports of brown bear trophies from British Columbia over concerns of unsustainable hunting pressure, of which residents of Europe were responsible for $1 / 3$ the total number of bears killed in the province. Despite this, brown bear trophies were reportedly being smuggled into the EU facilitated by the Canadian authorities and trophy hunting industry (Gaius 2018). In Russia, while the hunting of some bears is allowed with a valid permit, bear populations are under threat from poaching and illegal harvest for trade (Braden 2014). Thousands of bear paws have been seized by customs officers at the China-Russia Far East border alone - as recent as November 2019, 240 bear paws were seized by Russian authorities (Stewart 2019); in January 2018,867 bear paws along with an unknown quantity of bear teeth and claws were seized (Stewart 2018). Nevertheless, much remains unknown on the impact of hunting (i.e. trophy, illegal, etc.) and trade dynamics involving bears from these countries which clearly warrants further investigation.

There also appears to be demand for traditional medicines containing bear parts in the Czech Republic. These medicines are being smuggled in from Asia (primarily Vietnam and to a lesser extent mainland China and Hong Kong) in violation of CITES regulations. Nine of the seizures made had origins in Vietnam, with Vietnamese nationals involved. It is likely all medicines originating from Vietnam contained derivatives of the Asiatic black bear, as this species is the most commonly utilised species in Vietnam's domestic trade in bear bile medicines and the most frequently encountered species in the bear bile extraction facilities (bear farms) in Vietnam (Foley et al. 2011; Willcox et al. 2016). Bear bile in vodka is an unusual item, and this should be investigated further to determine if this is an emerging use for bear bile and what its purpose is. The demand for bear parts in traditional medicines, i.e., gallbladders and bile, is particularly significant in China and Vietnam (Mills and Servheen 1994; Shepherd and Nijman 2007; Foley et al. 2011; Burgess et al. 2014; Davis et al. 2016; Willcox et al. 2016; Gomez and Shepherd 2018). This demand has been the reported cause for bear declines in Cambodia, Lao PDR, Myanmar and Vietnam (Nijman et al. 2017; Crudge et al. 2018). China and Vietnam are also the major sources of processed bear bile medicines, and regardless of policies in place that prohibit the international export of these products, medicines manufactured in both China and Vietnam have been observed illegally for sale in other countries in Asia (Foley et al. 2011; Burgess et al. 2014; Gomez and Shepherd 2018) as well as the USA and Canada (WAP 2020). The Czech Republic has a relatively large Vietnamese community ( close to 60,000 in 2016 - Kim, Kim 2020), and it is therefore not surprising that there is some demand for traditional medicines used in Vietnam. Nevertheless, the trafficking of bear bile medicines from Vietnam is illegal, and steps are urgently needed to mitigate this particularly since it undermines conservation efforts in Vietnam to protect its bear species. Bear bile farming is not only illegal in Vietnam, but studies show that wild bears are poached to restock these facilities in violation of national laws (Crudge et al. 2018). Furthermore, these threats are amplified when considering that these market demands likely exists across the rest of Europe where a significant Asian community is present, as reported in the USA and Canada.

While the maximum penalty for individuals caught smuggling bear parts and derivatives into the Czech Republic is USD66,180, the highest penalty reported in this analysis was USD885, and it should be noted that this offence included multiple species and not only bears. The lowest penalty handed down was USD20, and the average fine was USD175 - far below the potential maximum amount and therefore unlikely to be a deterrent. For context, it is necessary to consider the average income in the Czech Republic; in 2005, the average 
income was USD13,346, and by 2018, the average income had risen to USD23,069 (https://data.worldbank.org/ indicator/NY.GDP.PCAP.CD?locations=CZ). Clearly penalties should be increased if the law is to serve as a deterrent.

The Czech Republic has been a Party to CITES since 1993 and was previously a Party to CITES as part of the former Czechoslovakia since 1992. Notably, seizures of bears, their parts and products, made in the Czech Republic have all originated from CITES Parties as well. While there are no specific bilateral agreements between the Czech Republic and Canada or Russia, there is a 2015 bilateral agreement between the Czech Republic and Vietnam to counter illegal wildlife trade, the Declaration on Cooperation in the field of CITES implementation, signed by the Deputy Minister of the Environment of the Czech Republic and the Deputy Minister of Agriculture and Rural Development of Vietnam. This declaration is aimed at improving the sharing of information in implementing CITES and to raise awareness regarding the protection and conservation of wildlife, which therefore includes joint regulation of trade in bear parts and derivatives between the two countries. Of the eight species of bears in the world, six are listed on CITES Appendix I (the exceptions being the American black bear, polar bear and certain populations of the brown bear), prohibiting the international commercial trade in wild animals as markets demands are considered a significant enough threat to the conservation status of remaining populations, all of which are reported to be in decline. Despite this, a black market in bears, their parts and derivatives persists across their range both domestically and internationally. This study shows just how global the threat of illegal wildlife trade is to bear species with the international trafficking of bear parts and derivatives into the Czech Republic from eight countries and territories from as far as Vietnam to neighbouring Slovakia, yet, only a small facet of this illegal trade has been examined outside of Asia.

As the illegal trade in bear parts and derivatives in the Czech Republic is clearly in need of attention, we make the following recommendations:

\section{Monitoring of traditional medicine trade in the Czech Republic} Retail outlets selling traditional medicines, especially within communities that are known for using bear parts and derivatives, should be monitored, and all incidents of illegal trade should be prosecuted to the full extent of the law so as to serve as a deterrent. Consumer awareness-raising programmes should be initiated within these communities, especially the Vietnamese community, to ensure the public is aware of the Czech Republic's legislation prohibiting the buying, selling and possessing of bear parts and products. Finally, the Czech Environmental Inspectorate should enhance collaborative efforts with Vietnam's Ministry of Agriculture and Rural Development (MARD) as the CITES Management Authority and CITES Enforcement Focal Point of Vietnam, to jointly tackle the smuggling of bear parts and derivatives from Vietnam to the Czech Republic.

Monitoring of trophies entering the Czech Republic As most cases involved trophies, we recommend the authorities carefully monitor the import of trophies and potential leakage of illegally sourced bears (or restricted bear parts, such as gallbladders) into the trade, especially from Canada and Russia. Both Canada and Russia allow for export of bear trophies, so an investigation into the reasons behind smuggling versus legal trade should be considered. The Czech Environmental Inspectorate should enhance collaborative efforts with the CITES Enforcement Focal Point of Canada (the Wildlife Enforcement Directorate) and the CITES Management Authority of Russia (the Ministry of Natural Resources and Environment of the Russian Federation) to jointly tackle the illegal trade in bear trophies. Discrepancies between numbers of reported imports and reported exports should be investigated further by the CITES Management Authorities of the Czech Republic and relevant exporting countries, especially Canada and Russia.

Strengthened deterrents The government of the Czech Republic should consider handing down larger fines for bear trafficking crimes as current fines are low and are not likely to serve as a deterrent. Ideally, fines should be greater than the value of the contraband.

Raising public awareness to catalyse participation in antiillegal wildlife trade efforts Raising awareness of the illegal trade in wildlife, and bears in particular, should be increased through public awareness campaigns, such as the Czech Republic's Stolen Wildlife Campaign (http://www. stolenwildlife.org/), to discourage illegal trade and consumption of bears and to encourage the public to report incidents of selling, buying and possession of illegal wildlife, including traditional medicines claiming to contain bear parts, bear trophies such as the skulls and skins and other parts and products derived from bears.

Acknowledgements We would like to thank the Czech Environmental Inspectorate for making their data available for this analysis. We thank Loretta Shepherd, Pauline Verheij and Sarah Heinrich for valuable comments on an earlier draft. We also commend the officers of the Czech Environmental Inspectorate involved in making these seizures for their vigilance and effort.

Data availability Not applicable.

\section{Compliance with ethical standards}

Conflict of interest The authors declare that they have no conflict of interest.

Ethics approval We declare that there have been no ethical violations in this work. 
Consent to participate All authors agreed to participate in this work.

Consent for publication All authors consent to the submission of this manuscript for publication.

\section{Code availability Not applicable.}

Open Access This article is licensed under a Creative Commons Attribution 4.0 International License, which permits use, sharing, adaptation, distribution and reproduction in any medium or format, as long as you give appropriate credit to the original author(s) and the source, provide a link to the Creative Commons licence, and indicate if changes were made. The images or other third party material in this article are included in the article's Creative Commons licence, unless indicated otherwise in a credit line to the material. If material is not included in the article's Creative Commons licence and your intended use is not permitted by statutory regulation or exceeds the permitted use, you will need to obtain permission directly from the copyright holder. To view a copy of this licence, visit http://creativecommons.org/licenses/by/4.0/.

\section{References}

Auliya M, Altherr S, Ariano-Sanchez D, Baard EH, Brown C, Brown RM, Cantu J-C, Gentile G, Gildenhuys P, Henningheim E (2016) Trade in live reptiles, its impact on wild populations, and the role of the European market. Biol Conserv 204:103-119

Braden K (2014) Illegal recreational hunting in Russia: the role of social norms and elite violators. Eurasian Geogr Econ 55(5):457-490

Burgess EA, Stoner SS, Foley KE (2014) Brought to bear: an analysis of seizures across Asia (2000-2011). TRAFFIC, Petaling Jaya, Selangor, Malaysia

Challender D, Baille J, Waterman C, Pietersen D, Nash H, Wicker L, Parker K, Thomson P, Nguyen TV, Hywood L, Shepherd CR (2016) On scaling up pangolin conservation. Traffic Bull 28(1): 19-21

Crudge B, Nguyen T, Cao T (2018) The challenges and conservation implications of bear bile farming in Viet Nam. Oryx 1-8

D'Cruze N, Sarma UK, Mookerjee A, Singh B, Louis J, Mahapatra RP, Jaiswal VP, Roy TK, Kumari I, Menon V (2011) Dancing bears in India: a sloth bear status report. Ursus 22(2):99-105

Davis EO, O'Conner D, Crudge B, Carignan A, Glikman JA, BrowneNuñez C, Hunt M (2016) Understanding public perceptions and motivations around bear part use: a study in northern Laos of attitudes of Chinese tourists and Lao PDR nationals. Biol Conserv 203: $282 \mathrm{e} 289$

Foley KE, Stengel CJ, Shepherd CR (2011) Pills, powders, vials and flakes: the bear bile trade in Asia. TRAFFIC Southeast Asia, Petaling Jaya, Selangor, Malaysia

Gaius J (2018) Grizzly trophies in Europe: are B.C. grizzly bear parts being unlawfully imported into the EU? David Suzuki Foundation. https://davidsuzuki.org/wp-content/uploads/2018/07/GrizzlyTrophies-in-Europe-DSF-report-July2018-final.pdf (Accessed 14 May 2020)

Gomez L, Shepherd CR (2018) Trade in bears in Lao PDR with observations from market surveys and seizure data. Glob Ecol Conserv 15(2018):e00415
Gomez L, Shepherd CR (2019) Bearly on the radar - an analysis of seizures of bears in Indonesia. Eur J Wildl Res 65(6). https://doi. org/10.1007/s10344-019-1323-1

Gomez L, Leupen BTC, Tian KH (2016) The trade of African pangolins to Asia: a brief case study of pangolin shipments from Nigeria. Traffic Bull 28(1):3-5

Gomez L, Shepherd CR, Khoo MS (2020) Illegal trade of sun bear parts in the Malaysian states of Sabah and Sarawak. Endanger Species Res 41:279-287. https://doi.org/10.3354/esr01028

Gupta BK, Singh R, Satyanarayan K, Seshamani G (2007) Trade in bears and their parts in India: threats to conservation of bears. In: Williamson, D. (Ed). Proceedings of the fourth international symposium on the trade in bear parts. TRAFFIC East Asia-Japan

Harrison RD, Sreekar R, Brodie JF, Brook S, Luskin M, O'Kelly H, Rao M, Scheffers B, Velho N (2016) Impacts of hunting on tropical forests in Southeast Asia. Conserv Biol 30:972-981

Heinrich S, Wittmann TA, Prowse TAA, Ross JV, Delean S, Shepherd CR, Cassey P (2016) Where did all the pangolins go? International CITES trade in pangolin species. Glob Ecol Conserv 8:241-253

Kim TS (2020) Young migrant Vietnamese in the Czech Republic reflect diasporic contexts in their identification of cultural proximity with Korean media. J Intercult Stud 41(4):524-539

Lee SL, Burgess EA, Chng SCL (2015) Hard to bear: an assessment of trade in bear bile and gall bladder in Malaysia. TRAFFIC. Petaling Jaya, Selangor, Malaysia

Lee JGH, Chng SCL and Eaton JA (2016) Conservation strategy for Southeast Asian songbirds in trade. Recommendations from the first Asian Songbird Trade Crisis Summit 2015 held in Jurong Bird Park, Singapore, 27-29 September 2015. Wildlife Reserves Singapore. TRAFFIC Southeast Asia

Livingstone E, Gomez L, Bouhuys J (2018) A review of bear farming and bear trade in Lao People's Democratic Republic. Glob Ecol Conserv 13(2018): 00380

McLellan BN, Proctor MF, Huber D, Michel S (2017) Ursus arctos (amended version of 2017 assessment). The IUCN Red List of Threatened Species 2017: e.T41688A121229971. https://doi.org/ 10.2305/IUCN.UK.2017-3.RLTS.T41688A121229971.en. Downloaded on 21 March 2020

Mills J, Servheen C (1994) The Asian trade in bears and bear parts: impacts and conservation recommendations. Int Conf Bear Res Manage 9(1):161-167

Nijman V, Oo H, Shwe NM (2017) Assessing the illegal bear trade in Myanmar through conversations with poachers: topology, perceptions and trade links to China. Hum Dimens Wildl 22:172-182

Nijman V, Nekaris KAI, Imron MA (2019) Asian Songbird Crisis also affects unprotected species. Oryx 53:13

Shepherd CR, Janssen J, Noseworthy J (2019) A case for listing the Union Island Gecko Gonatodes daudini in the Appendices of CITES. Glob Ecol Conserv 17:e00549

Shepherd CR, Nijman V (2007) The trade in bear parts from Myanmar: an illustration of the ineffectiveness of enforcement of international wildlife trade regulations. Biodivers Conserv 17:35-42

Stanford CB, Iverson JB, Rhodin AGJ, van Dijk PP, Mittermeier RA et al (2020) Turtles and tortoises are in trouble. Curr Biol 30:R721-R735

Stewart W (2018) Bear and tiger body parts including hacked off tails and genitals are seized from smugglers taking them to China where they are believed to make men better in bed. MailOnline. https://www. dailymail.co.uk/news/article-5340069/Animal-parts-believedmake-men-better-bed-seized.html (Accessed 20 Jan 2018)

Stewart W (2019) Grisly cargo of 240 bear paws which were 'destined for China to be turned into food and traditional medicine' is seized by Russian security agents. MailOnline. https://www.dailymail.co.uk/ 
news/article-7676875/Grisly-cargo-240-bear-paws-60-illegallyslaughtered-animals-seized.html (Accessed 12 Nov 2019)

UNODC (2020) World Wildlife Crime Report. United Nations Office on Drugs and Crime, 2020

Van Uhm DP (2016) The illegal wildlife trade: inside the world of poachers, smugglers and traders. Springer, Switzerland, 2016

Voigt M, Wich SA, Ancrenaz M, Meijaard E, Abram N, Banes GL, Campbell-Smith G, d'Arcy L, Delgado RA, Erman A, Gaveau D, Goosens B, Heinicke S, Houghton M, Husson SJ, Leiman A, Llano S, Makinuddin N, Marshall A, Meididit A, Miettinen J, Mundry R, Musnanda N, Nurcahyo A, Odom K, Panda A, Prasetyo D, Priadjati A, Purnomo RA, Russon AE, Santika T, Sihite J, Spehar S, Struebig M, Sulbaran-Romero E, Tiiu A, Wells J, Wilson KA, Kuhl HS (2018) Global demand for natural resources eliminated more than 100,000 Bornean Orangutans. Curr Biol 28:761-769
Willcox D, Nguyen MDT, Gomez L (2016) An assessment of trade in bear bile and gall bladder in Viet Nam. TRAFFIC. Petaling Jaya, Selangor, Malaysia

Wong R, Krishnasamy K (2019) Skin and Bones Unresolved: an analysis of tiger seizures from 2000-2018. TRAFFIC Southeast Asia, Petaling Jaya, Selangor, Malaysia

World Animal Protection (WAP) (2020) Cruel cures: the industry behind bear bile production and how to end it. https://www.dropbox.com/s/ 2kzpdkfjn4vh347/Bear\%20Bile\%20Report_Cruel\%20Cures FINAL_compressed.pdf?dl=0 (Accessed 1 March 2020)

WWF (2018) Living Planet Report - 2018: Aiming Higher. Grooten, M. and Almond, R.E.A.(Eds). WWF, Gland, Switzerland

Publisher's note Springer Nature remains neutral with regard to jurisdictional claims in published maps and institutional affiliations. 